\title{
MITIGASI DAN PEMETAAN JALUR ALTERNATIF EVAKUASI CEPAT LINGKAR KAMPUS POLNAM UNTUK ANTISIPASI POTENSI TSUNAMI PASCA GEMPA AMBON BERBASIS GIS DAN FOTO UDARA
}

\author{
Steanly R.R.Pattiselanno ${ }^{1)}$, Agus K.Soetrisno ${ }^{2)}$ \\ ${ }^{1,2)}$ Jurusan Teknik Sipil - Politeknik Negeri Ambon \\ ${ }^{1)}$ steanly.r.r.pattiselanno@gmail.com, ${ }^{2)}$ agus.k.soetrisno@gmail.com
}

\begin{abstract}
The 2019 Maluku earthquake with a magnitude of 6.5 that occurred on September 26, 2019, at 08.46 WIT, with the epicenter $42 \mathrm{~km}$ northeast of Ambon City at a depth of $10 \mathrm{~km}$. Massive displacement with a simultaneous movement pattern after moving away from the coast to an altitude in the north, and combined with only 1 (one) road segment leading to a height resulting in a permanent jam (dead lock) along the "evacuation route". This had an impact on the POLNAM campus community, due to the earthquake which occurred during office hours. The objectives of this research are, spatially $(G I S)$ trying to determine fast evacuation routes that have potential but have not been used in the POLNAM campus area by using aerial photographs combined with the 20-20-20 concept which has become BNPB's guideline in tsunami mitigation in Indonesia. By utilizing geographic information systems, aerial photographs are identified to obtain potential evacuation routes and safe evacuation zones. The result is a system that forms a fast evacuation route on the POLNAM campus to anticipate the impact of the tsunami disaster from the identification of aerial photos, consisting of 7 gathering points, 4 doors for 4 evacuation accesses with a length of route A, $184 \mathrm{~m}$ and a slope of $7.6 \%$, line B with a length of $192 \mathrm{~m}$ and a slope of $6.8 \%$, line $\mathrm{C}$ with a length of $234 \mathrm{~m}$ and a slope of $6.4 \%$, and line $\mathrm{D}$ with a length of $169 \mathrm{~m}$ and a slope of $9.5 \%$, and 2 safe zones for evacuation with an area of safe zone 1 are $9,990 \mathrm{~m}^{2}$ (12.5\% slope), safe zone 2 with an area of 5,237 $\mathrm{m}^{2}$ (slope of $8.75 \%$ ). For both the safe zone is located above an altitude of $>20 \mathrm{mDPL}$. The movement pattern to reach two safe zones, then divided into 4 evacuation routes and 7 gathering points, each safe zone 1 is supported by 2 evacuation routes, namely evacuation route A from door A, and evacuation route B from door B. Safe zone 2 is supported by 2 evacuation routes, namely evacuation route $C$ from door $C$, and evacuation route $D$ from door D. Evacuation door A serves gathering points 1 to 3, evacuation door B serves gathering points 2 to 4 , evacuation door $\mathrm{C}$ serves gathering points 4 and 6 , evacuation gate $\mathrm{D}$ serves gathering points 5 and 7 .
\end{abstract}

\section{ABSTRAK}

Gempa bumi Maluku tahun 2019 dengan magnitudo 6,5 yang terjadi tanggal 26 September 2019, pada Pukul 08.46 WIT, dengan pusat gempa berjarak $42 \mathrm{~km}$ Timur Laut Kota Ambon di kedalaman $10 \mathrm{Km}$. Pengungsian secara masif yang pola pergerakannya serempak setelah menjauhi pesisir pantai menuju pegunungan di arah utara, dan dikombinasikan dengan hanya 1 (satu) ruas jalan menuju pegunungan mengakibatkan kemacetan permanen (dead lock) sepanjang "jalur pengungsian". Ini berimbas pada masyarakat Kampus POLNAM, akibat gempa yang terjadi saat jam kantor. Tujuan penelitian ini adalah, secara spasial (GIS) mencoba menentukan jalur-jalur evakuasi cepat yang selama ini punya potensi tapi belum dimanfaatkan di kawasan lingkar Kampus POLNAM dengan menggunakan foto udara yang dikombinasikan dengan konsep 20-20-20 yang sudah menjadi pedoman BNPB dalam mitigasi tsunami di Indonesia. Dengan memanfaatkan sistem informasi geografis, hasil foto udara diidentifikasi untuk memperoleh jalur potensial evakuasi dan area zone aman evakuasi. Hasilnya adalah sistem yang membentuk jalur evakuasi cepat di kampus POLNAM untuk antisipasi dampak bencana tsunami dari hasil identifikasi foto udara, terdiri dari 7 titik kumpul, 4 pintu untuk 4 jalur evakuasi dengan panjang jalur A, $184 \mathrm{~m}$ dan kemiringan jelajah 7,6\%, jalur B dengan panjang $192 \mathrm{~m}$ dan kemiringan 6,8\%, jalur $\mathrm{C}$ dengan panjang $234 \mathrm{~m}$ dan kemiringan 6,4\%, dan jalur D dengan panjang $169 \mathrm{~m}$ dan kemiringan 9,5\%, serta 2 zone aman untuk evakuasi dengan luas zone aman 1 adalah $9.990 \mathrm{~m} 2$ (kemiringan 12,5\%), zone aman 2 dengan luas $5.237 \mathrm{~m} 2$ (kemiringan $8,75 \%$ ). Untuk kedua zone aman terletak di atas ketinggian $>20$ mDPL. Pengaturan pola pergerakan untuk mencapai dua zona aman, maka dibagi atas 4 jalur evakuasi dan 7 titik kumpul, masing-masing zona aman 1 disuport oleh 2 jalur evakuasi yaitu jalur evakuasi A dari pintu A, dan jalur evakuasi B dari pintu B. Zona aman 2 disuport oleh 2 jalur evakuasi yaitu jalur evakuasi $C$ dari pintu $C$, dan jalur evakuasi $D$ dari pintu $D$. Pintu evakuasi A melayani titik kumpul 1 sampai 3, pintu evakuasi B melayani titik kumpul 2 sampai 4, pintu evakuasi C melayani titik kumpul 4 dan 6, pintu evakuasi D melayani titik kumpul 5 dan 7.

Kata kunci: gempa; tsunami; jalur evakuasi; GIS 


\section{JURNAL SIMETRIK VOL.10, NO.2, DESEMBER 2020}

\section{PENDAHULUAN}

Gempa bumi Maluku tahun 2019 dengan magnitudo 6,5 yang terjadi tanggal 26 September 2019, pada Pukul 08.46 WIT, dengan pusat gempa berjarak 42 km Timur Laut Kota Ambon di kedalaman $10 \mathrm{Km}$, sangat berpengaruh terhadap pola aktifitas seluruh lapisan masyarakat, tanpa terkecuali masyarakat kampus. Aktifitas perkuliahan di Politeknik Negeri Ambon (POLNAM) yang saat itu baru dimulai pun merasakan dampak langsung dengan terjadinya kepanikan dan diikuti dengan pergerakan masyarakat secara masal dan serempak (mengungsi) menuju area dengan ketinggian yang dirasakan aman dari terjangan "Tsunami" yang ditakutkan menjadi bentuk "bencana susulan" yang biasanya mengiringi gempa dengan kekuatan magnitudo sebesar saat itu. Badan Meteorologi Klimatologi dan Geofisika (BMKG) Stasiun Ambon mencatat sebanyak 5.100 kali gempa bumi mengguncang wilayah Maluku sepanjang tahun 2019. Gempa Ambon sendiri, ada 3 kejadian gempa besar yang terjadi bertapatan dengan waktu operasional kerja, yaitu berkekuatan magnitudo 6,5 pada 26 September 2019, berkekuatan magnitudo 5,2 (10 Oktober) dan gempa magnitudo 5,1 (12 November 2019). (https://regional.kompas.com/read/

2020/01/02/16241081/5100-gempa-bumi-guncangmaluku-sepanjang-2019).

Pengungsian secara masif yang pola pergerakannya serempak setelah gempa menjauhi pesisir pantai menuju pegunungan di arah utara, dan dikombinasikan dengan hanya 1 (satu) ruas jalan menuju pegunungan mengakibatkan kemacetan permanen (dead lock) sepanjang "jalur pengungsian". Hal yang sama berdampak ke lingkungan Kampus POLNAM, dimana ketika masyarakat kampus yang mengevakuasi diri keluar dari kampus, sama-sama terjebak dead lock bersama masyarakat luar kampus dan masyarakat dari banyak instansi lainnya di lingkar kampus, sehingga akhirnya semuanya diperhadapkan pada kondisi harus pasrah menunggu kemacetan terurai dengan sendirinya tanpa bisa kemana-mana. Hal ini akan sangat berbahaya, jika bencana tsunami benarbenar terjadi. Jika tsunami benar-benar terjadi, maka konsep 20-20-20 (gempa 20 detik, minimum 20 menit untuk evakuasi sejak gempa dengan elevasi lokasi evakuasi minimum 20 meter DPL) yang sudah menjadi pedoman BNPB dalam mitigasi tsunami di Indonesia dapat diterapkan. Secara teori seorang manusia normal berjalan dengan kecepatan $80 \mathrm{~cm} /$ detik. Jika orang tersebut berjalan selama 20 menit, maka jarak yang ditempuh sudah $960 \mathrm{~m}$. Dalam banyak tempat, zona kuning untuk kawasan bahaya tsunami setempat umumnya hingga sejauh 500 meter dari garis pantai. "Jadi dengan berjalan sejauh $960 \mathrm{~m}$, secara teknis sudah keluar dari kawasan bahaya tsunami zona kuning," (https://www.kompas.com/tren/read/2019/ 11/17/063000465/rumus-20-20-20-saat-peringatandini-tsunami-seberapa-efektif?page $=$ all.)

Secara eksisting, lokasi evakuasi yang ideal (elevasi $\geq 20 \mathrm{~m}$ DPL), terletak tepat di belakang kampus POLNAM ke arah utara karena terdapat perbukitan dengan cukup banyak jalur tradisional yang sering dipakai masyarakat lingkar kampus untuk membuat perkebunan. Melihat potensi itu, maka dirasa perlu dilakukan penelitian berupa kajian secara spasial dengan memanfaatkan system informasi geografis dan foto udara dari drone untuk mengidentifikasi jalur alternatif evakuasi dan zone aman dari terjangan tsunami di sekitar kampus POLNAM. Sasarannya agar mengurangi potensi korban jiwa yang tidak diinginkan saat terjadi bencana tsunami.

\section{TINJAUAN PUSTAKA}

\subsection{Tsunami}

Tsunami yang dalam bahasa Jepang, terdiri dari dua suku kata, yaitu "tsu" (pelabuhan/laut) dan "nami" (gelombang). US Army Corps of Engineers (1990) dalam Kodoatie dan Rustam Syarief (2006), mendefinisikan tsunami adalah gelombang laut gravitasi dengan periode panjang yang disebabkan oleh gangguan seperti gempa, gerakan patahan, longsoran, letusan gunung berapi dibawah laut, jatuhnya bendabenda langit (meteor), atau letusan (exploison) di dekat permukaan laut.

Gelombang tsunami adalah gelombang panjang yang tidak dispersive, mengalami refraksi, defraksi, shoaling, refleksi, dan run up danmampu menjalar dengan kecepatan $\geq 900 \mathrm{~km} / \mathrm{jam}$, terutama jika diakibatkan gempabumi di dasar laut. Panjang gelombang antara dua puncak tsunami bisa $\geq 100 \mathrm{~km}$ di laut lepas dan selisih waktu antara puncak gelombangnya antara 10 menit sampai 1 jam. Saat mencapai area dangkal di pantai, teluk, atau muara sungai, kecepatan gelombang tsunami menurun, tapi tinggi gelombangnya bisa meningkat puluhan meter dan bersifat merusak.

Menurut BMKG dalam Bambang Marwanta (2005), magnitudo tsunami di Indonesia berkisar 1,5 4,5 skala Imamura.

\subsection{Gempa}

Gempa yang potensial berdampak menimbulkan tsunami biasanya terjadi dasar laut dengan kedalaman pusat gempa kurang dari $60 \mathrm{~km}$, dan dengan magnitude gempa lebih dari 6,0 skala Richter. Klasifikasi gempa menurut kedalamannya, yaitu gempa dangkal $(0<\mathrm{h}<$ $60 \mathrm{~km})$, gempa menengah $(60<\mathrm{h}<300 \mathrm{~km})$, dan gempa dalam $(\mathrm{h}>300 \mathrm{~km})$. Hagiwara (1964) dalam Bambang Marwanta (2005), mengklasifikasi gempa menurut besar kecilnya magnitude (M) yaitu: gempa besar $(M \geq 7)$, gempa sedang $(5 \leq M<7)$, gempa kecil $(3 \leq M<5)$, gempa mikro $(1 \leq M<3)$, gempa ultra mikro $(\mathrm{M}<1)$.

Hubungan matematis besaran magnitudo tsunami (m) dengan magnitudo gempa (M) di Indonesia menurut IIDA dalam Bambang Marwanta (2005), adalah:

$$
m=2,26 M-14,18 \ldots \ldots \ldots \ldots \ldots \ldots \ldots . . .1)
$$




\section{JURNAL SIMETRIK VOL.10, NO.2, DESEMBER 2020}

dimana:

$$
\begin{aligned}
& \mathrm{m} \text { : Magnitudo tsunami; } \\
& \mathrm{M} \text { : Magnitudo Gempa (Richter) }
\end{aligned}
$$

Secara empiris, menurut IIDA (1963) dalam Bambang Marwanta (2005) hubungan magnitudo tsunami (m) dengan tinggi gelombang tsunami (run up) terlihat dalam Tabel1. berikut:

Tabel 1.Hubungan umum magnitudo tsunami dengan tinggi run up di pantai

\begin{tabular}{|c|c|c|}
\hline $\begin{array}{c}\text { Klasifikasi Magnitudo } \\
\text { Tsunami }\end{array}$ & Energi ( $\mathbf{~ 1 0 2 3}$ ergs) & $\begin{array}{c}\text { Tinggi maksimum } \\
\text { rambatan naik, } \text { run up } \\
(\mathbf{m})\end{array}$ \\
\hline \hline 5.0 & 25.6 & $>32.0$ \\
\hline 4.5 & 12.8 & $24-32$ \\
\hline 4.0 & 6.4 & $16-24$ \\
\hline 3.5 & 3.2 & $12-16$ \\
\hline 3.0 & 1.6 & $8-12$ \\
\hline 2.5 & 0.8 & $6-8$ \\
\hline 2.0 & 0.4 & $4-6$ \\
\hline 1.5 & 0.2 & $3-4$ \\
\hline 1.0 & 0.1 & $2-3$ \\
\hline 0.5 & 0.05 & $1.5-2$ \\
\hline 0.0 & 0.025 & $1-1.5$ \\
\hline-0.5 & 0.0125 & $0.75-1$ \\
\hline-1.0 & 0.006 & $0.5-0.75$ \\
\hline-1.5 & 0.003 & $0.3-0.05$ \\
\hline-2.5 & 0.0015 & $<0.3$ \\
\hline
\end{tabular}

Sumber: Bambang Marwanta, 2005

\subsection{Sistem Informasi Geografis (SIG/GIS)}

Definisi Sistem lnformasi Geografis (SIG) (Prahasta, 2009:116), adalah sistem yang berbasiskan komputer yang digunakan untuk menyimpan dan memanipulasi informasi-informasi geografis. SIG dirancang untuk mengumpulkan, menyimpan, dan menganalisis objek-objek dan fenomena dimana lokasi geografi merupakan karakteristik yang penting atau kritis yang dianalisis. Dengan demikian, SIG merupakan sistem komputer yang bereferensi geografi [Aronoff89]:

a. Masukan;

b. Manajemen data (penyimpanan dan pemanggilan data);

c. Analisis dan manipulasi data; dan

d. Keluaran.

Keunikan Sistem Informasi Geografis dibandingkan dengan sistem pengolahan basis data yang lain adalah kemampuannya untuk menyajikan informasi spasial maupun non-spasial secara bersamasama. Misalnya, penggunaan lahan pada suatu daerah dapat disajikan dalam bentuk batas-batas yang masingmasing mempunyai atribut penjelasan dalam bentuk tulisan maupun angka.

\section{- Georeferencing}

Georeferencing adalah proses pemberian referensi spasial pada data raster (citra satelit, foto udara, peta hasil scanning (analog) dan peta digital. Referensi spasial yang diberikan dapat berupa sistem koordinat geografis (geographic coordinate system) atau sistem koordinat proyeksi (projected) dengan bentuk proyeksi UTM (Universal transferse Mercantor). Selain data raster, ada juga data vector yang telah mempunyai sistem koordinat proyeksi karena terdiri dari bentuk titik (point), garis (polyline), dan area (polygon). Jadi tujuan data vector adalah untuk melengkapi data raster selaku data utama dan memberikan informasi spasial (posisi, panjang, luas, arah).

\section{- $\quad$ Foto Udara}

Foto udara dipakai untuk melihat permukaan bumi yang relatif tidak luas (lebih sempit) dari citra satelit, dan diperoleh dengan cara melakukan pengambilan gambar dengan menggunakan pesawat terbang maupun pesawat nir-awak (drone). Foto udara sebagai salah satu bentuk data raster bisa diolah jika telah memiliki referensi spasial lewat proses rektifikasi yaitu menyimpan hasil georeferencing.

\section{- Data Atribut}

Jenis data yang mempresentasikan aspek-aspek deskriptif dari fenomena yang bersangkutan hingga dimensi waktunya. Jenis data ini sering disebut data atribut atau non-spasial.Data atribut merupakan keterangan dari datavector maupun raster. Data atribut terdiri dari :

a. Formulir dan daftar, dengan format (kode alfabetik, kode alfa numeric dan angka);

b. Laporan lengkap, dengan format (kata kalimat dan keterangan lain);

c. Keterangan gambar (graphyc chart), dengan format (kata, angka, keterangan penunjuk liputan area, keterangan simbol.

- Data Manipulation dan Analysis

Merupakan subsistem yang menentukan informasi-informasi yang dapat dihasilkan oleh SIG.Fungsi analisis spasial dari SIG terdiri dari:

a. Klasifikasi (reclassify), berfungsi mengklasifikasikan atau mengklasifikasi kembali suatu data spasial/atribut menjadi data spasial yang baru dengan menggunakan kriteria tertentu.

b. Jaringan (network), berfungsi merujuk pada data-data spasial yang berupa titik-titik atau garis-garis sebagai suatu jaringan yang tidak terpisahkan.

c. Tumpang susun (overlay) berfungsi menghasilkan data spasial baru dari minimal dua data spasial yang manjadi masukannya.Terdapat beberapa cara melakukan tumpang susun data grafisyaitu:

- Identity (overlay antara dua data grafis dengan menggunakan data grafis pertama sebagai acuan batas luarnya);

- Union (overlay berupa penggabungan antara dua data grafis);

- Lntersection (overlay antara dua data grafis tetapi apabila batas luar dari dua data grafis tersebut tidak sama, maka yang dioverlay hanya pada daerah yang bertampalan);

d. Buffering.Fungsi ini akan menghasilkan data spasial baru yang berbentuk polygon atau zone dengan jarak tertentu dari data spasial yang menjadi masukannya. Data spasial titik akan meghasilkan data spasial baru yang berupa lingkaran-lingkaran yang mengelilingi 


\section{JURNAL SIMETRIK VOL.10, NO.2, DESEMBER 2020}

titik-titik pusatnya. Untuk data spasial garis maka akan menghasilkan lingkaran-lingkaran yang melingkupi garis-garis. Demikian untuk data spasial polygon;

- $\quad$ Digital Terrain Model (DTM)

Digital Terrain Model (DTM) atau biasa disebut sebagai Digital Elevation Model (DEM) adalah salah satu metode pendekatan yang bisa dipakai untuk memodelkan relief permukaan bumi dalam bentuk tiga dimensi, sebagai model, analisa, dan representasi fenomena yang berhubungan dengan topografi atau permukaan lain.Terdapat beberapa metode untuk mempresentasikan bentuk permukaan bumi menggunakan DTM, diantaranya yaitu model grid/raster (menyajikan permukaan bumi dalam matriks atau piksel-piksel kecil berbentuk bujur sangkar yang mewakili luasan sebenarnya pada permukaan bumi. Setiap piksel datam model ini memiliki atribut ketinggian (elevasi) masing-masing), dan model TIN (Triangulated lrregular Network) dengan menyajikan model permukaan sebagai sekumpulan bidang-bidang kecil (facet) berbentuk segitiga yang saling berhubungan dari titik-titik yang memiliki atribut koordinat horizontal (x,y) dan koordinat vertikal (elevasi).

\section{METODOLOGI}

\subsection{Lokasi Penelitian}

Lokasi penelitian di Kampus Politeknik Negeri Ambon (POLNAM), yang beralamat di Jalan Ir. M. Putuhena, Wailela - Desa Rumahtiga Ambon,danterbentang pada koordinat UTM 408.902,11 BT - 409.267,48 BT, dan 9.595.364,45 LS 9.595.715,06 LS, seperti pada Gambar 1:

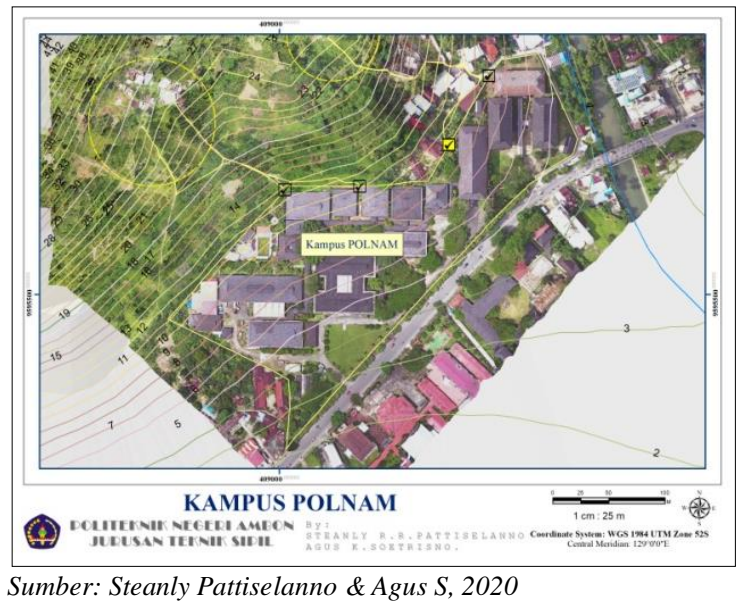

Gambar 1. Lokasi Studi (Kampus POLNAM)

\subsection{Jenis dan Sumber Data}

Jenis data yang dikumpulkan terdiri atas data ruang dan data non ruang yang menggambarkan karakteristik lokasi studi. Data-data yang dibutuhkan adalah:

1) Peta kontur/topografi (sumber BIG, digitasi peta RBI Pulau Ambon, NLP 2612-23, Edisi I Tahun 2008);
2) Peta Daerah Aliran Sungai (sumber hasil digitasi Peta RBI);

3) Rekaman Foto Udara terektifikasi koordinat UTM dan elevasi DPL.

\subsection{Metode Analisa Data}

Penelitian ini dilakukan dengan beberapa tahapan yakni:

1) Membuat peta tematik kontur/topografi Pulau Ambon (*.shp) dari digitasi olahan peta RBI Pulau Ambon, NLP 2612-23, Edisi I Tahun 2008 dengan aplikasi ArcGIS MAP 10.4;

2) Membuat foto udara yang berisi informasi spasial DEM berupa data DTM dengan aplikasi Pix4DCapture untuk pengaturan lintasan drone dan Agisoft Metashape untuk running data DEM/DTM.

\section{HASIL DAN PEMBAHASAN}

\subsection{Hasil Penelitian}

Letak kampus Politeknik Negeri Ambon terbentang pada koordinat UTM 408.902,11 BT 409.267,48 BT, dan 9.595.364,45 LS - 9.595.715,06 LS, dengan luas $43.018 \mathrm{~m}^{2}$ atau 4,3 Ha. Ketinggian rata-rata permukaan lahan Kampus POLNAM adalah atara $5-13 \mathrm{mDPL}$. Hal ini menjadikan lokasi POLNAM rentan terhadap bencana tsunami,namunjika merujuk pada konsep 20-20-20 (gempa 20 detik, minimum 20 menit untuk evakuasi sejak gempa dengan elevasi lokasi evakuasi minimum 20 meter DPL) yang sudah menjadi pedoman BNPB dalam mitigasi tsunami di Indonesia, maka posisi kampus POLNAM relatif aman sebab hanya berjarak $\pm 75 \mathrm{~m}$ ke arah utara dari POLNAM terdapat lereng dengan elevasi lebih dari 20 m. (Gambar 1.)

Dari hasil foto udara yang dilengkapi informasi spasial, maka dapat diidentifikasi kebutuhan area dan jalur untuk membentuk sistem jalur alternatif evakuasi cepat lingkar kampus POLNAM untuk antisipasi potensi tsunami pasca gempa Ambon. Hasil identifikasinya, dipetakan 2 area potensial sebagai zone aman dengan kriteria elevasi di atas $20 \mathrm{~m}$ dan memiliki akses berupa jalur tradisional (jalan tanah) ke kebun rakyat oleh petani dan masyarakat yang bertempat tinggal di area bukit arah utara kampus POLNAM. Akses menuju zone aman yang bisa diidentifikasi adalah 4 akses dan 4 pintu evakuasi yang bisa disiapkan di sisi utara kampus POLNAM. Identifikasi potensial titik kumpul sementara di lingkungan kampus POLNAM sebelum evakuasi ke zone aman adalah 7 titik kumpul yang memenuhi syarat yaitu area terbuka dan datar sebelum mengarah ke pintu evakuasi.

\subsection{Pembahasan}

Identifikasi jalur alternatif evakuasi cepat lingkar kampus POLNAM untuk antisipasi potensi tsunami pasca gempa Ambon, sebagai berikut:

- $\quad$ Titik Kumpul berupa area terbuka di dekat pintu keluar dari gedung-gedung di lingkungan kampus POLNAM dan memiliki akses relatif bebas untuk 


\section{JURNAL SIMETRIK VOL.10, NO.2, DESEMBER 2020}

menuju ke arah utara sisi kampus POLNAM berupa 7 titik kumpul (Gambar 2.);

- Zone aman ditetapkan pada area perbukitan di belakang kampus POLNAM arah utara, yang memenuhi syarat minimum ketinggian di atas 20 $\mathrm{m}$ dengan kemiringan lereng rata-rata untuk zone aman 1 adalah $12,5 \%$ dan luas $9.990 \mathrm{~m}^{2}$, serta zone aman 2 dengan kemiringan lereng adalah $8,75 \%$ dan luas $5.237 \mathrm{~m}^{2}$, seperti pada Gambar 2:

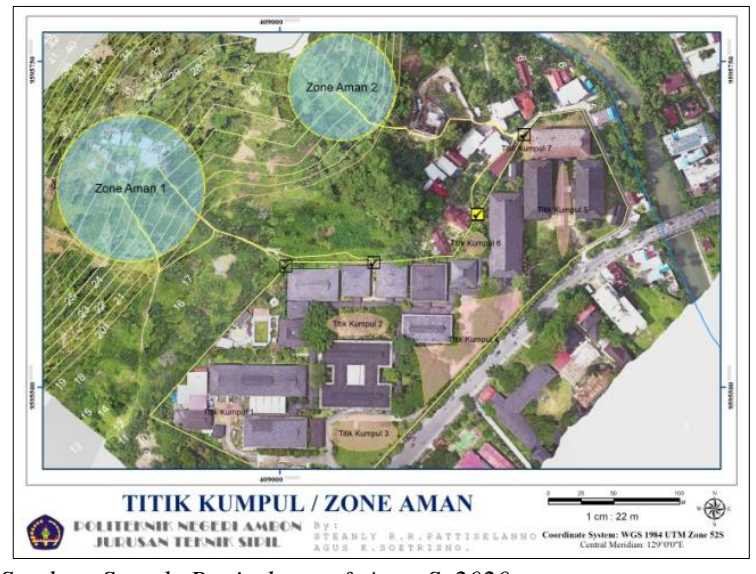

Sumber: Steanly Pattiselanno \& Agus S, 2020

Gambar 2. Peta Titik Kumpul / Zone Aman

- $\quad$ Ada 4 jalur evakuasi potesial untuk menuju ke 2 zone aman yang terdiri atas 2 jalur evakuasi per masing-masing zone aman 1 dan 2 . Jalur A menuju ke zone aman 1 dengan panjang $184 \mathrm{~m}$ dimana kemiringan lereng rata-rata $7,6 \%$, jalur $B$ menuju ke zone aman 1 dengan panjang $192 \mathrm{~m}$ dimana kemiringan lereng rata-rata 6,8\%. Jalur $\mathrm{C}$ menuju ke zone aman 2 dengan panjang $234 \mathrm{~m}$ dimana kemiringan lereng rata-rata $6,4 \%$, jalur D menuju ke zone aman 2 dengan panjang $169 \mathrm{~m}$ dimana kemiringan lereng rata-rata $9,5 \%$ (Gambar 3.);

- Pintu evakuasi yang ditempatkan sesuai jalur evakuasi, ada 4 titik yaitu pintu evakuasi A pada koordinat (409.004,67 BT dan 9.595.592,92 LS), pintu evakuasi B $(409.071,59$ BT dan 9.595.595,77 LS), pintu evakuasi C (409.150,94 BT dan 9.595.632,87 LS), dan pintu evakuasi D (409.186,66BT dan 9.595.693,95 LS), seperti pada Gambar 4.

- Rata-rata waktu tempuh berdasarkan teori kecepatan berjalan orang normal $(80 \mathrm{~cm} / \mathrm{det})$ yang dibutuhkan sejak seseorang keluar dari pintu evakuasi sampai dengan zona aman adalah:

- Dari pintu evakuasi A sampai zone aman 1 adalah 3 menit 50 detik.

- Dari pintu evakuasi B sampai zone aman 1 adalah 4 menit.

- Dari pintu evakuasi C sampai zone aman 2 adalah 4 menit 52,5 detik.

- Dari pintu evakuasi D sampai zone aman 2 adalah 3 menit 31,25 detik.

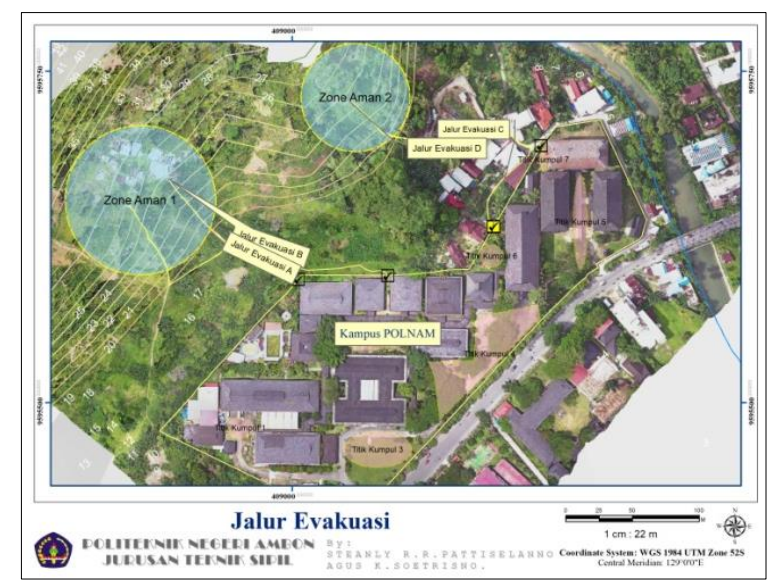

Sumber: Steanly Pattiselanno \& Agus S, 2020

Gambar 3. Peta Jalur Evakuasi

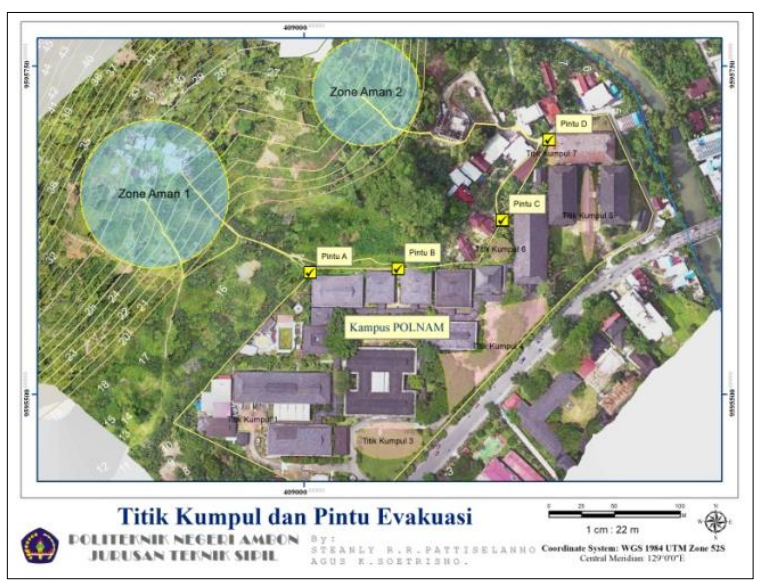

Sumber: Steanly Pattiselanno \& Agus S, 2020

Gambar 4. Peta Titik Kumpul dan Pintu Evakuasi

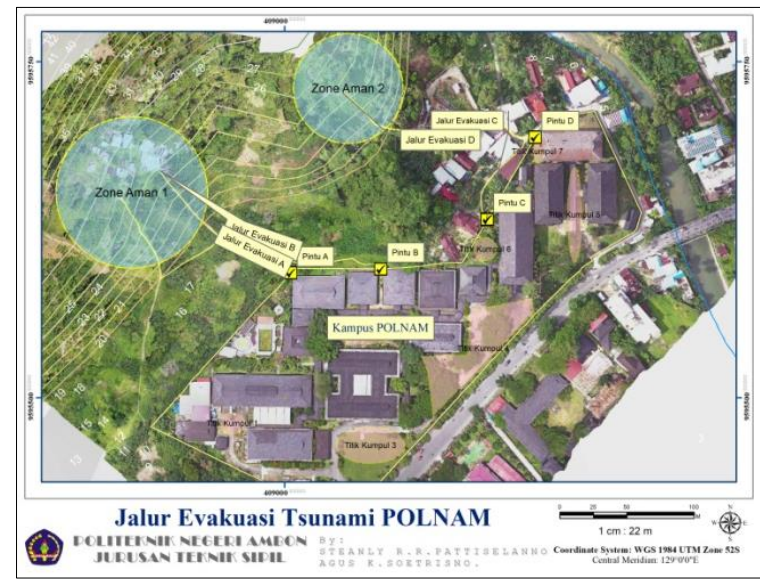

Sumber: Steanly Pattiselanno \& Agus S, 2020

Gambar 5. Peta Jalur Evakuasi Tsunami POLNAM

\section{PENUTUP}

5.1. Kesimpulan

Kesimpulandari hasil penelitian ini:

1) Sistem yang membentuk jalur evakuasi cepat di Kampus POLNAM untuk antisipasi dampak bencana tsunami dari hasil identifikasi foto udara, terdiri dari 7 titik kumpul, 4 pintu untuk 4 jalur 


\section{JURNAL SIMETRIK VOL.10, NO.2, DESEMBER 2020}

evakuasi dengan panjang jalur A, $184 \mathrm{~m}$ dan kemiringan jelajah $7,6 \%$, jalur $\mathrm{B}$ dengan panjang $192 \mathrm{~m}$ dan kemiringan $6,8 \%$, jalur $\mathrm{C}$ dengan panjang $234 \mathrm{~m}$ dan kemiringan $6,4 \%$, dan jalur $\mathrm{D}$ dengan panjang $169 \mathrm{~m}$ dan kemiringan 9,5\%, serta 2 zone aman untuk evakuasi dengan luas zone aman 1 adalah $9.990 \mathrm{~m}^{2}$ (kemiringan $12,5 \%$ ), zone aman 2 dengan luas $5.237 \mathrm{~m}^{2}$ (kemiringan $8,75 \%$ ). Untuk kedua zone aman terletak di atas ketinggian $>20 \mathrm{mDPL}$.

2) Pengaturan pola pergerakan untuk mencapai dua zona aman, maka dibagi atas 4 jalur evakuasi dan 7 titik kumpul, masing-masing zona aman 1 disuport oleh 2 jalur evakuasi yaitu jalur evakuasi A dari pintu A, dan jalur evakuasi B dari pintu B. Zona aman 2 disuport oleh 2 jalur evakuasi yaitu jalur evakuasi C dari pintu AC, dan jalur evakuasi D dari pintu D. Pintu evakuasi A melayani titik kumpul $1-3$, pintu evakuasi B melayani titik kumpul $2-4$, pintu evakuasi $\mathrm{C}$ melayani titik kumpul 4 dan 6, pintu evakuasi D melayani titik kumpul 5 dan 7.

\subsection{Saran}

Untuk mengantisipasi timbulnya korban akibat bencana tsunami jika benar terjadi, maka perlu dipertimbangkan penyiapan jalur-jalur evakuasi alternatif dengan mengoptimalkan keunggulan topografi dan kearifan lokal setempat di daerah,misalnya dengan karakteristik seperti Pulau Ambon yang bentang alamnya memungkinkan untuk bisa lebih cepat mengakses posisi ketinggian yang aman tanpa perlu melewati jalur infrastruktur resmi seperti jalan yang dibangun oleh pemerintah dengan kapasitas yang masih terbatas.

\section{DAFTAR PUSTAKA}

Badan Informasi Geospasial. 2008.

Arief Mustofa Nur. 2010. Jurnal Geografi (Tahun 2010) Hal 66-73. GEMPA BUMI, TSUNAMI DAN MITIGASINYA.[https://journal.unnes. ac.id/nju/index.php/JG/article/view/92]

Bambang Marwanta.2005. Jurnal Alami. Vol. 10, No. 2 (Tahun 2005) Hal 29-36. Tsunami di Indonesia dan Upaya Mitigasinya. [https://www.neliti.com/publications/195692/ts unami-di-indonesia-dan-upaya-mitigasinya

Dwi Jokowinarno. 2011. Jurnal Rekayasa Vol. 15 No. 1.(April 2011) Hal 13-20. MITIGASI BENCANA TSUNAMI DI WILAYAH PESISIR LAMPUNG. [https://www.neliti. com/publications/139673/mitigasi-bencanatsunami-di-wilayah-pesisir-lampung]

Kodoatie Robert dan Rustam sjarief. 2006. Pengelolaan Bencana Terpadu (Banjir, longsor, kekeringan dan tsunami), Yarsif Watampone, Jakarta [https://www.neliti.com/journals/alami-jurnalteknologi-reduksi-risiko-bencana]

Kukuh Setio Utomo, Chatarina Muryani, Setya Nugraha. 2018. Jurnal GeoEco. ISSN: 24600768. Vol. 4, No. 1 (Januari 2018) Hal. 68-76.
E-ISSN: 2597-6044. KAJIAN KESIAPSIAGAAN TERHADAP BENCANA TSUNAMI DI KECAMATAN PURING KABUPATEN KEBUMEN TAHUN 2016. [https://103.23.224.239/GeoEco/article/view/1 9180]

Priska Gardeni Nahak, Djunaedi dan Tedi Wonlele. 2017. Studi Perencanaan Mitigasi Bencana Tsunami di Daerah Wisata Pantai Tablolong [https://jurnal.polban.ac.id/potensi/article/view/ 898]

Rusli, Irjan, dan Ariska Rudyanto. 2010. Jurnal Neutrino Vol.2 No.2 April 2010, Hal. 164-182. Pemodelan Tsunami Sebagai Bahan Mitigasi Bencana (Studi Kasus Sumenep dan Kepulauannya).[https://www.researchgate.net/p ublication/290500320]

S. Hidayatullah Santius. (2015). Jurnal Permukiman Vol. 10 No. 2 November 2015 : 92-105. PEMODELAN TINGKAT RISIKO BENCANA TSUNAMI PADA PERMUKIMANDI KOTA BENGKULU MENGGUNAKAN SISTEM INFORMASI GEOGRAFIS.[http://103.12.84.119/index.php/ JP/article/view/10]

Pattiselanno, Steanly. 2015. Penentuan batas DAS dan pembuatan jaringan aliran Sungai Wailela dengan menggunakan Geographic Information System (GIS). Penelitian Mandiri. Ambon.

Prahasta, E. 2009. Sistem Informasi Geografis: Konsep-konsep dasar (Perspektif Geodesi \& Geomatika. Penerbit Informatika. Bandung.

Prahasta, E. 2004. Sistem Informasi Geografis: Tutorial Arc View. Penerbit Informatika. Bandung.

https://regional.kompas.com/read/2020/01/02/162410 81/5100-gempa-bumi-guncang-malukusepanjang-2019.

https://sains.kompas.com/read/2019/07/21/070000923 /viral-potensi-tsunami-selatan-jawa-bnpbminta-warga-ingat-rumus-20-20-20?page $=$ all.

https://www.kompas.com/tren/read/2019/11/17/06300 0465/rumus-20-20-20-saat-peringatan-dinitsunami-seberapa-efektif?page $=$ all. 